\title{
Synthesis, X-Ray Crystal Structure, Bactericidal and Kinetic Study of some Mononuclear Zinc and Mercury Complexes Supported by Bisaroylhydrazone Derivatives
}

\author{
Refaa Burhan Kazem and Ahmed Jasim M Al-Karawi* \\ Department of Chemistry, College of Science, Al-Mustansiriya University, P.O Box 46010, \\ Baghdad-Iraq. \\ * Corresponding author: ahmedalkarawi@unomustansiriyah.edu.iq.
}

\begin{abstract}
This work includes the synthesis of two derivatives of cyclohexane bisaroylhydrazone: $\left(\mathrm{L}_{1}\right)$ and $\left(\mathrm{L}_{2}\right)$. These compounds were synthesized via the condensation reaction of 1,2-cyclohexanedione with an appropriate hydrazide derivative in acidic medium. The prepared ligands were reacted with zinc chloride or mercury chloride under ambient conditions. Consequently, mononuclear type complexes: $\left[\mathrm{Zn}\left(\mathrm{L}_{1}\right) \mathrm{Cl}_{2}\right](\mathbf{1}),\left[\mathrm{Zn}\left(\mathrm{L}_{2}\right) \mathrm{Cl}_{2}\right] \cdot \mathrm{CH}_{3} \mathrm{CN}(\mathbf{2})$. [ $\left.\mathrm{Hg}\left(\mathrm{L}_{1}\right) \mathrm{Cl}_{2}\right]$ (3) and $\left[\mathrm{Hg}\left(\mathrm{L}_{2}\right) \mathrm{Cl}_{2}\right] \cdot \mathrm{CH}_{3} \mathrm{CN}$ (4) were obtained. Different techniques have been used to characterize the prepared organic ligands and their metal complexes (X-ray single crystal crystallography and microelemental analyses in addition to infrared, nuclear magnetic resonance, X-ray powder diffraction, Ultraviolate-visible-Near infrared, and mass spectroscopes). Depending upon the X-ray crystallography, it seems that the obtained products of $1,2,3$ and 4 are mononuclear complexes. Each structure comprises a $[\mathrm{M}(\mathrm{L})]^{2+}$ core. The kinetic of complex formation of $\mathbf{2}$ was investigated and the results are investigated and compare with that of $\mathbf{4}$. The study showed in general, the formation of $\mathbf{2}$ and $\mathbf{4}$ in one phase with a first-order type reaction. Antibacterial activities of all the prepared compounds against some pathogenic bacteria (Staphylococcus aureus and Escherichia coli) were evaluated, which exhibit a good growth inhibitory activity.

[DOI: $\underline{10.22401 / A N J S .22 .1 .03]}$
\end{abstract}

Keywords: Mononuclear complexes, Bisaroylhydrazone, Kinetic studies.

\section{Introduction}

In general, there has been an increased interest in hydrazide and their derivatives, particularly in the last few years, related to their coordinative and pharmacological activity as well as their use in analytical chemistry as metal-extracting agents [1-11]. These compounds possess diverse biological and pharmacological properties such as antimicrobial, anti-inflammatory, analgesic, antifungal, anti-tubercular, antiviral, anticancer, antiplatelet, antimalarial, anticonvulsant, cardio protective, antihelmintic, antiprotozoal, antitrypanosomal, antischistosomiasis..etc.

Benzohydrazide and their derivatives are poly-functional molecules (containing multifunctional groups in their structures like $-\mathrm{CO}$, $-\mathrm{NH}-$ and $-\mathrm{NH}_{2}$ ). Due to that, a wide range of compounds have been prepared based on benzohydrazide derivative $[1,4,6,9,11]$. Among all of these, aroylhydrozones (Schiff bases) represent one of the most known and important compounds. These compounds possessing an azomethine $-\mathrm{NHN}=\mathrm{CH}$ - proton constitute an important class of compounds for different biological activities : antimicrobial, anticovulsant, analgesic, antiplatelet, antiinflammatory, anti-tubercular, anticancer and antitumor as well as a new drug development $[6-8,11]$.

Reaction of aroylhydrazide with di-aldehyde or di-ketone produces bisaroylhydrazones $[3,12-$ 14]. Bisaroylhydrazones are known to be a class of versatile ligands, capable of generating different molecular architectures (even have been used as starting materials for the formation of 1,2,3,4- tetrazine, 1,3,4oxadiazine or 1,2,3-triazine derivatives [12])

This work is focus on the synthesis of new bisaroylhydrazone derivatives and study their coordination behavior toward $\mathrm{Zn}$ (II) and $\mathrm{Hg}$ (II) ions as a part of our continuation work in this field $[15,16]$

\section{Experimental \\ Materials and instruments}

All the reagents that are used in this work are purchased from commercial sources (Sigma-Aldrich Co. and Alfa Aesar Co.). ${ }^{1} \mathrm{H}$ and ${ }^{13} \mathrm{C}\left\{{ }^{1} \mathrm{H}\right\} \mathrm{NMR}$ spectra were measured in DMSO- $_{6}$ using a Bruker $400 \mathrm{MHz}$ spectrometer. Mass spectra of the ligands were 
obtained using Orbitrap LTQ XL-Thermo Fisher scientific mass spectrometer. Infrared spectra were performed using a Vertex 70FTIR spectrometer. Electronic spectra were carried out with a Shimadzu UV-3101PC spectrophotometer for $\left(1 \times 10^{-3} \mathrm{M}\right)$ of the samples in DMSO at RT. EuroEA Elemental Analyzer was used to determine the elemental analyses $(\mathrm{C}, \mathrm{H}$ and $\mathrm{N})$. While $(\mathrm{Zn}$ and $\mathrm{Hg}$ ) were measured with a $7300 \mathrm{~V}$ ICP-OES PerkinElmer-Optima Spectrometer. X-ray powder diffraction patterns were obtained with a Stoe Powder Diffractometer System Stadi P., using $\mathrm{Cu}$-Ka radiation $(\lambda=1.54178 \AA$ ).

\section{Synthesis of ligands (general procedure)}

A mixture of an appropriate hydrazide derivative $(1.46 \mathrm{~g}, 10.7 \mathrm{mmol}$ for benzhydrazide $)$ and $\quad(1.78 \mathrm{~g}, \quad 10.7 \mathrm{mmol}$ for 4 methoxybenzhydrazide), 1,2-cyclohexanedione $(0.6 \mathrm{~g}, 5.35 \mathrm{mmol})$ and glacial acetic acid $(2 \mathrm{ml})$ in methanol $\left(35 \mathrm{~cm}^{3}\right)$ was reflux for $5 \mathrm{~h}$. The light yellow microcrystalline powder that deposited is filtered and washed with $\mathrm{CH}_{3} \mathrm{OH}$. Yields: $\left(1.40 \mathrm{~g}, 90 \%\right.$ for $\left.\mathrm{L}_{1}\right)$ and $(1.70 \mathrm{~g}, 93 \%$ for $\left.\mathrm{L}_{2}\right)$. Microelemental analysis\% calculated (found): for $\mathrm{L}_{1}$ : C 68.9 (68.8), H $5.8(5.8), \mathrm{N}$ 16.1 (16.1), for $\mathrm{L}_{2}$ : C 64.7 (64.6), H 5.9 (5.8), N 13.7 (13.5). Spectroscopic data for $\mathrm{L}_{1}:{ }^{1} \mathrm{H}$ NMR spectrum $\delta / \mathrm{ppm}$ : cyclohexane protons: $1.74\left(4 \mathrm{H}, \mathrm{m}, \mathrm{CH}_{2}\right), 2.63\left(2 \mathrm{H}, \mathrm{t}, J_{\mathrm{HH}}=3.1 \mathrm{~Hz}\right.$, $\left.\mathrm{CH}_{2}\right), 2.83\left(2 \mathrm{H}, \mathrm{t}, J_{\mathrm{HH}}=3.1 \mathrm{~Hz}, \mathrm{CH}_{2}\right)$; other protons: $7.52-8.22(10 \mathrm{H}, \mathrm{m}$, aromatic protons), $11.15(1 \mathrm{H}, \mathrm{s}, \mathrm{NH}-$ keto form $), 14.45$ (1H, s, OH-enol form). ${ }^{13} \mathrm{C}\left\{{ }^{1} \mathrm{H}\right\} \mathrm{NMR}$ spectrum $\delta / \mathrm{ppm}:$ 21.54-34.24 (cyclohexane carbons), 128.88-133.44 (aromatic carbons), $153.55(\mathrm{C}=\mathrm{N}), 163.74(\mathrm{C}=\mathrm{O})$. Mass spect. $(\mathrm{m} / \mathrm{z})$ : 348. IR spectrum $\mathrm{v} / \mathrm{cm}^{-1}: 3217$ (w-m, $v(\mathrm{NH})), 3060$ (w, v(C-H aromatic)), 2960 (w, $\mathrm{v}_{\mathrm{as}}(\mathrm{C}-\mathrm{H})$ of $\left.\mathrm{CH}_{2}\right), 2876\left(\mathrm{w}, \mathrm{v}_{\mathrm{s}}(\mathrm{C}-\mathrm{H})\right.$ of $\left.\mathrm{CH}_{2}\right), 1656$ (s, v(C=O)), 1602, 1578 (m, $v(\mathrm{C}=\mathrm{C}$ aromatic $)), \quad 1518 \quad(\mathrm{~m}, \quad \mathrm{v}(\mathrm{C}=\mathrm{N}))$. Spectroscopic data for $\mathrm{L}_{2}:{ }^{1} \mathrm{H}$ NMR spectrum $\delta /$ ppm: cyclohexane protons: $1.75(4 \mathrm{H}, \mathrm{m}$, $\left.\mathrm{CH}_{2}\right), 2.63\left(2 \mathrm{H}, \mathrm{t}, J_{\mathrm{HH}}=3.1 \mathrm{~Hz}, \mathrm{CH}_{2}\right), 2.83$ $\left(2 \mathrm{H}, \mathrm{t}, J_{\mathrm{HH}}=3.1 \mathrm{~Hz}, \mathrm{CH}_{2}\right)$; other protons: 3.85 $\left(6 \mathrm{H}, \mathrm{s}, \mathrm{OCH}_{3}\right), 7.03-8.22(8 \mathrm{H}, \mathrm{m}$, aromatic protons), 10.95 (1H, s, NH-keto form), 14.34 (1H, s, OH-enol form). ${ }^{13} \mathrm{C}\left\{{ }^{1} \mathrm{H}\right\}$ NMR spectrum $\delta / \mathrm{ppm}:$ 21.77-34.43 (cyclohexane carbons $), \quad 56.18 \quad\left(\mathrm{OCH}_{3}\right), \quad 114.36-131.16$ (aromatic carbons), $153.17(\mathrm{C}=\mathrm{N}), 163.13$ $(\mathrm{C}=\mathrm{O})$. Mass spect. $(\mathrm{m} / \mathrm{z}): 408$. IR spectrum v/cm ${ }^{-1}: 3365$ (w-m, v(NH)), 3059 (w, v(C-H aromatic) $), 2986\left(\mathrm{w}, \mathrm{v}_{\mathrm{as}}(\mathrm{C}-\mathrm{H})\right.$ of $\left.\mathrm{CH}_{3}\right), 2946$ (w, vas $(\mathrm{C}-\mathrm{H})$ of $\left.\mathrm{CH}_{2}\right), 2873\left(\mathrm{w}, \mathrm{v}_{\mathrm{s}}(\mathrm{C}-\mathrm{H})\right.$ of $\left.\mathrm{CH}_{3}\right), 2833$ (w, $v_{\mathrm{s}}(\mathrm{C}-\mathrm{H})$ of $\left.\mathrm{CH}_{2}\right), 1678$ (s, $v(\mathrm{C}=\mathrm{O})), 1602,1575(\mathrm{~m}, \mathrm{v}(\mathrm{C}=\mathrm{C}$ aromatic $))$, $1528(\mathrm{~m}, \mathrm{v}(\mathrm{C}=\mathrm{N})), 1240(\mathrm{vs}, \mathrm{v}(\mathrm{C}-\mathrm{O}))$.

\section{Synthesis of metal complexes \\ [ $\left.\mathbf{Z n}\left(\mathbf{L}_{1}\right) \mathbf{C l}_{2}\right]$ compound (1)}

$\mathrm{ZnCl}_{2}$ (0.05 g, $\left.0.367 \mathrm{mmol}\right)$ was dissolved in $\mathrm{CH}_{3} \mathrm{CN}\left(6 \mathrm{~cm}^{3}\right)$ and added to $\mathrm{L}_{1}(0.127 \mathrm{~g}$, $0.367 \mathrm{mmol})$ in $\mathrm{CH}_{3} \mathrm{CN}\left(35 \mathrm{~cm}^{3}\right)$. After couple of days yellow crystals formed which are filtered and washed with $\mathrm{CH}_{3} \mathrm{CN}$. Yield: $0.125 \mathrm{~g}, \quad 59 \%$. Microelemental analysis\% calculated (found): C49.6(49.4), H4.2(4.4), N11.6(11.5), Zn13.5(13.3). ${ }^{1} \mathrm{H}$ NMR spectrum

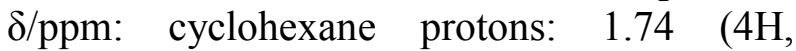
$\left.\mathrm{m}, \mathrm{CH}_{2}\right), 2.64\left(2 \mathrm{H}, \mathrm{t}, J_{\mathrm{HH}}=3.1 \mathrm{~Hz}, \mathrm{CH}_{2}\right), 2.83$ $\left(\mathrm{CH}_{2}, \mathrm{t}, 2 \mathrm{H}, J_{\mathrm{HH}}=3.1 \mathrm{~Hz}\right)$; other protons: 7.50-8.19 (10H, m, aromatic protons), 11.14 (1H, s, NH-keto form), $14.41(1 \mathrm{H}, \mathrm{s}, \mathrm{OH}-\mathrm{enol}$ form). ${ }^{13} \mathrm{C}\left\{{ }^{1} \mathrm{H}\right\} \mathrm{NMR}$ spectrum $\delta / \mathrm{ppm}$ : $22.42-$ 35.13 (cyclohexane carbons), 129.79-134.32 (aromatic carbons), $154.53(\mathrm{C}=\mathrm{N}), 164.64$ $(\mathrm{C}=\mathrm{O})$. IR spectrum $\mathrm{v} / \mathrm{cm}^{-1}: 3196 \quad(\mathrm{w}-\mathrm{m}$, v(NH)), 3064 (w, v(C-H aromatic)), 2957 (w, $\mathrm{v}_{\mathrm{as}}(\mathrm{C}-\mathrm{H})$ of $\left.\mathrm{CH}_{2}\right), 2880\left(\mathrm{w}, \mathrm{v}_{\mathrm{s}}(\mathrm{C}-\mathrm{H})\right.$ of $\left.\mathrm{CH}_{2}\right), 1667(\mathrm{~s}, \mathrm{v}(\mathrm{C}=\mathrm{O})), 1600,1583(\mathrm{~m}$, $v(\mathrm{C}=\mathrm{C}$ aromatic $)), 1531(\mathrm{~m}, \mathrm{v}(\mathrm{C}=\mathrm{N}))$.

\section{$\left[\mathrm{Zn}\left(\mathbf{L}_{2}\right) \mathbf{C l}_{2}\right] \cdot \mathrm{CH}_{3} \mathrm{CN}$ compound (2)}

$\mathrm{ZnCl}_{2}(0.06 \mathrm{~g}, 0.431 \mathrm{mmol})$ was dissolved in $\mathrm{CH}_{3} \mathrm{CN}\left(6 \mathrm{~cm}^{3}\right)$ and added to $\mathrm{L}_{2}(0.176 \mathrm{~g}$, $0.431 \mathrm{mmol})$ in $\mathrm{CH}_{3} \mathrm{CN}\left(35 \mathrm{~cm}^{3}\right)$. After couple of days yellow crystals formed which are filtered and washed with $\mathrm{CH}_{3} \mathrm{CN}$. Yield: $0.135 \mathrm{~g}, 62.7 \%$. Microelemental analysis\% calculated(found): $\quad$ C49.2(49.1), H4.6(4.5), N12.0(11.6), Zn11.2(11.0). ${ }^{1} \mathrm{H}$ NMR spectrum

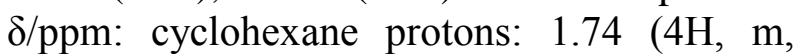
$\left.\mathrm{CH}_{2}\right), 2.62\left(2 \mathrm{H}, \mathrm{t}, J_{\mathrm{HH}}=3.1 \mathrm{~Hz}, \mathrm{CH}_{2}\right), 2.82$ $\left(2 \mathrm{H}, \mathrm{t}, J_{\mathrm{HH}}=3.1 \mathrm{~Hz}, \mathrm{CH}_{2}\right)$; other protons: 3.85 $\left(6 \mathrm{H}, \mathrm{s}, \mathrm{OCH}_{3}\right), 7.03-8.23(8 \mathrm{H}, \mathrm{m}$, aromatic protons), 10.95 (1H, s, NH-keto form), 14.34 $\left(1 \mathrm{H}, \quad\right.$ s, OH-enol form). ${ }^{13} \mathrm{C}\left\{{ }^{1} \mathrm{H}\right\} \mathrm{NMR}$ spectrum $\delta / \mathrm{ppm}$ : 21.54-34.19 (cyclohexane carbons), $\quad 55.93 \quad\left(\mathrm{OCH}_{3}\right), \quad 114.15-130.96$ (aromatic carbons), $151.33 \quad(\mathrm{C}=\mathrm{N}), 162.91$ 
$(\mathrm{C}=\mathrm{O})$. IR spectrum $\mathrm{v} / \mathrm{cm}^{-1}: 3365$ (w-m, v(NH)), 3068 (w, v(C-H aromatic)), 2977 $\left(\mathrm{w}, \mathrm{v}_{\mathrm{as}}(\mathrm{C}-\mathrm{H})\right.$ of $\left.\mathrm{CH}_{3}\right), 2935\left(\mathrm{w}, \mathrm{v}_{\mathrm{as}}(\mathrm{C}-\mathrm{H})\right.$ of $\left.\mathrm{CH}_{2}\right), 2870$ (w, $\mathrm{v}_{\mathrm{s}}(\mathrm{C}-\mathrm{H})$ of $\left.\mathrm{CH}_{3}\right), 2831$ (w, $v_{s}(\mathrm{C}-\mathrm{H})$ of $\left.\mathrm{CH}_{2}\right), 1666(\mathrm{~s}, \mathrm{v}(\mathrm{C}=\mathrm{O})), 1602$, $1576(\mathrm{~m}, \quad \mathrm{v}(\mathrm{C}=\mathrm{C}$ aromatic $)), 1528(\mathrm{~m}$, $v(\mathrm{C}=\mathrm{N})), 1250(\mathrm{vs}, \mathrm{v}(\mathrm{C}-\mathrm{O}))$.

\section{$\left[\mathrm{Hg}\left(\mathbf{L}_{1}\right) \mathbf{C l}_{2}\right]$ compound (3)}

$\mathrm{HgCl}_{2}(0.10 \mathrm{~g}, 0.360 \mathrm{mmol})$ was dissolved in $\mathrm{CH}_{3} \mathrm{OH}\left(6 \mathrm{~cm}^{3}\right)$ and added to $\mathrm{L}_{1}(0.125 \mathrm{~g}$, $0.360 \mathrm{mmol})$ in $\mathrm{CH}_{3} \mathrm{OH}\left(40 \mathrm{~cm}^{3}\right)$. The mixture has been stirred for few minutes and a huge amount of precipitate formed. This precipitate was isolated and the clear solution was kept closed. After couple of days, yellow small crystals were deposited, which were filtered and washed with $\mathrm{CH}_{3} \mathrm{OH}$. Yield: $0.17 \mathrm{~g}$, $63.8 \%$. Microelemental analysis\% calculated (found): C38.8(38.9), H3.3(3.2), N9.0(9.1), Hg32.4(32.2). ${ }^{1} \mathrm{H}$ NMR spectrum $\delta / \mathrm{ppm}$ : cyclohexane protons: $1.75\left(4 \mathrm{H}, \mathrm{m}, \mathrm{CH}_{2}\right), 2.91$ $\left(4 \mathrm{H}, \mathrm{t}, J_{\mathrm{HH}}=3.2 \mathrm{~Hz}, \mathrm{CH}_{2}\right)$; other protons: 7.50-8.20 $(10 \mathrm{H}, \mathrm{m}$, aromatic protons $), 11.14$ (2H, s, NH). ${ }^{13} \mathrm{C}\left\{{ }^{1} \mathrm{H}\right\} \mathrm{NMR}$ spectrum $\delta / \mathrm{ppm}$ : 22.33-35.26 (cyclohexane carbons), 127.67134.47 (aromatic carbons), $155.77 \quad(\mathrm{C}=\mathrm{N})$, $160.56(\mathrm{C}=\mathrm{O})$. IR spectrum $\mathrm{v} / \mathrm{cm}^{-1}: 3230(\mathrm{w}-$ $\mathrm{m}, \mathrm{v}(\mathrm{NH})), 3054(\mathrm{w}, \mathrm{v}(\mathrm{C}-\mathrm{H}$ aromatic) $), 2948$ $\left(\mathrm{w}, \mathrm{v}_{\mathrm{as}}(\mathrm{C}-\mathrm{H})\right.$ of $\left.\mathrm{CH}_{2}\right), 2866\left(\mathrm{w}, \mathrm{v}_{\mathrm{s}}(\mathrm{C}-\mathrm{H})\right.$ of $\left.\mathrm{CH}_{2}\right), 1664$ (s, v $\left.(\mathrm{C}=\mathrm{O})\right), 1600,1575$ (m, $v(\mathrm{C}=\mathrm{C}$ aromatic $)), 1534(\mathrm{~m}, \mathrm{v}(\mathrm{C}=\mathrm{N}))$.

\section{$\left[\mathrm{Hg}\left(\mathrm{L}_{2}\right) \mathrm{Cl}_{2}\right] \cdot \mathrm{CH}_{3} \mathrm{CN}$ compound (4)}

The synthetic procedure of this compound can be found in our previous article [7]. Yield: $0.17 \mathrm{~g}, 66.3 \%$. Elemental analysis (\%) calc. (found): C 40.0 (39.9), H 3.8 (3.7), N 9.7 (9.5), $\mathrm{Hg} 27.8$ (27.5). ${ }^{1} \mathrm{H}$ NMR spectrum $\delta / \mathrm{ppm}$ : cyclohexane protons: $1.80\left(4 \mathrm{H}, \mathrm{m}, \mathrm{CH}_{2}\right), 2.91$ $\left(4 \mathrm{H}, \mathrm{t}, J_{\mathrm{HH}}=3.1 \mathrm{~Hz} \mathrm{C \textrm {CH } _ { 2 }}\right.$ ); other protons: 3.86 $\left(6 \mathrm{H}, \mathrm{s}, \mathrm{OCH}_{3}\right), 7.09-7.93(8 \mathrm{H}, \mathrm{m}$, aromatic protons), $11.54(2 \mathrm{H}, \mathrm{s}, \mathrm{NH}) .{ }^{13} \mathrm{C}\left\{{ }^{1} \mathrm{H}\right\} \mathrm{NMR}$ spectrum $\delta / \mathrm{ppm}$ : 21.21-32.56 (cyclohexane carbons), $54.41 \quad\left(\mathrm{OCH}_{3}\right), \quad 112.66-129.31$ (aromatic carbons), $151.18 \quad(\mathrm{C}=\mathrm{N}), 161.28$ $(\mathrm{C}=\mathrm{O})$. IR spectrum $\mathrm{v} / \mathrm{cm}^{-1}: 3263$ (w-m, v(NH)), 3071 (w, v(C-H aromatic)), 2972 (w, $\mathrm{v}_{\mathrm{as}}(\mathrm{C}-\mathrm{H})$ of $\left.\mathrm{CH}_{3}\right), 2946\left(\mathrm{w}, \mathrm{v}_{\mathrm{as}}(\mathrm{C}-\mathrm{H})\right.$ of $\left.\mathrm{CH}_{2}\right), 2879\left(\mathrm{w}, \mathrm{v}_{\mathrm{s}}(\mathrm{C}-\mathrm{H})\right.$ of $\left.\mathrm{CH}_{3}\right), 2840(\mathrm{w}$, $v_{\mathrm{s}}(\mathrm{C}-\mathrm{H})$ of $\left.\mathrm{CH}_{2}\right), 1657$ ( $\left.\mathrm{s}, \mathrm{v}(\mathrm{C}=\mathrm{O})\right), 1598$, $1575(\mathrm{~m}, \mathrm{v}(\mathrm{C}=\mathrm{C}$ aromatic $)), 1528(\mathrm{~m}, \mathrm{v}(\mathrm{C}=\mathrm{N}))$, 1248 (vs, v(C-O)).

\section{X-Ray Crystallography}

Crystals of the prepared compounds were analyzed and data were collected with $\operatorname{MoK} \alpha$ radiation on a Bruker APEX II system [17]. COSMO was used to determine the strategy of the data collection [18] and the integration was carried out with SAINT [19]. The corrections of multi-scan absorption were carried out with SADABS [20]. The structures of the prepared compounds were solved and refined with SHELXTL [21]. Crystal and refinement data for $\mathbf{1 - 4}$ are given in Table 1 .

\section{Kinetic Studies}

This study was carried out using an Applied Photophysics SX.18MV stopped-flow spectrophotometer. The solutions of $\mathrm{Zn}$ (II) ion and $\mathrm{L}_{2}$ in acetonitrile were prepared under $\mathrm{N}_{2}$ atmosphere and used within 30 minutes of preparation. Origin lab software was used to fit the absorbance-time traces to exponential curves. The obtained rate constants $\left(k_{o b s}\right)$ showed in the figures are the average of at least three experiments. All experiments were performed under pseudo-first-order conditions with the concentration of $L_{2}$ in an excess over the concentration of the $\mathrm{Zn}$ (II) ion.

\section{Bactericidal screening}

Antibacterial activities of all the prepared compounds against some pathogenic bacteria (Staphylococcus aureus and Escherichia coli) were evaluated by the disc diffusion method. The concentration of the solutions of compounds in DMSO is $\left(1 \times 10^{-4} \mathrm{M}\right)$. DMSO was used as control and gentamicin as the standard drug. The inhibition zones were measured after $24 \mathrm{~h}$.

\section{Results and Discussion}

\section{Synthesis and characterization of the prepared compounds}

$\mathrm{L}_{1}$ and $\mathrm{L}_{2}$ were synthesized by the condensation of an appropriate benzhydrazide derivative (benzhydrazide or 4methoxybenzhydrazide) and 1,2cyclohexanedione in methanol, Scheme (1). 


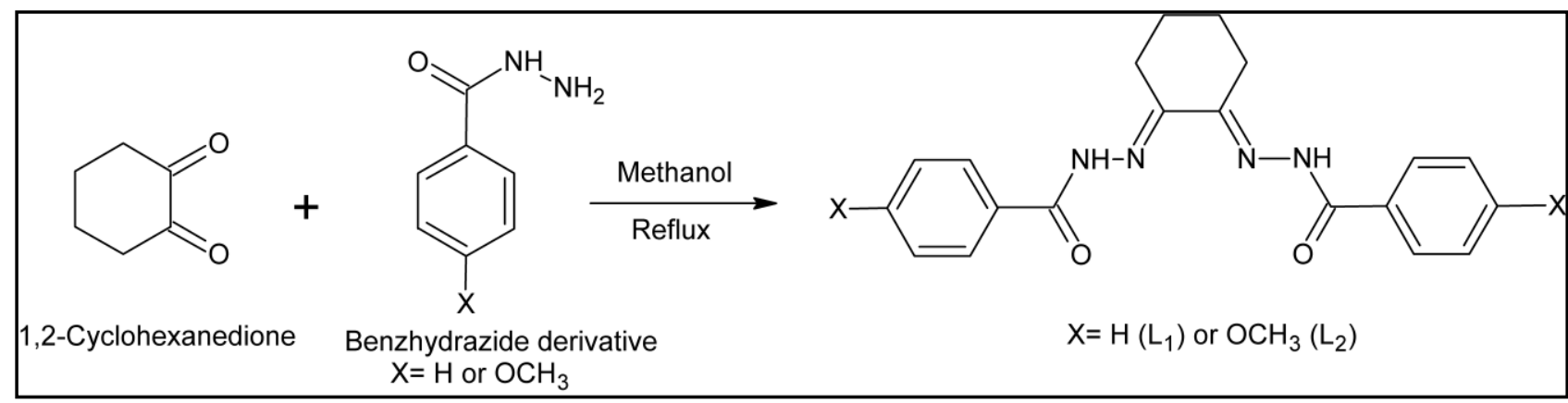

Scheme (1): General route for the preparation of ligands ( $L_{1}$ and $\left.L_{2}\right)$.

The reaction of equimolar amount of $\mathrm{L}_{1}$ or $\mathrm{L}_{2}$ and $\mathrm{HgCl}_{2}$ or $\mathrm{ZnCl}_{2}$, produced mononuclear type complexes: $\left[\mathrm{Zn}\left(\mathrm{L}_{1}\right) \mathrm{Cl}_{2}\right] \quad$ (1), $\left[\mathrm{Zn}\left(\mathrm{L}_{2}\right) \mathrm{Cl}_{2}\right] \cdot \mathrm{CH}_{3} \mathrm{CN}$ (2). [ $\left.\mathrm{Hg}\left(\mathrm{L}_{1}\right) \mathrm{Cl}_{2}\right]$ (3) and $\left[\mathrm{Hg}\left(\mathrm{L}_{2}\right) \mathrm{Cl}_{2}\right] . \mathrm{CH}_{3} \mathrm{CN}$ (4), Scheme (2).

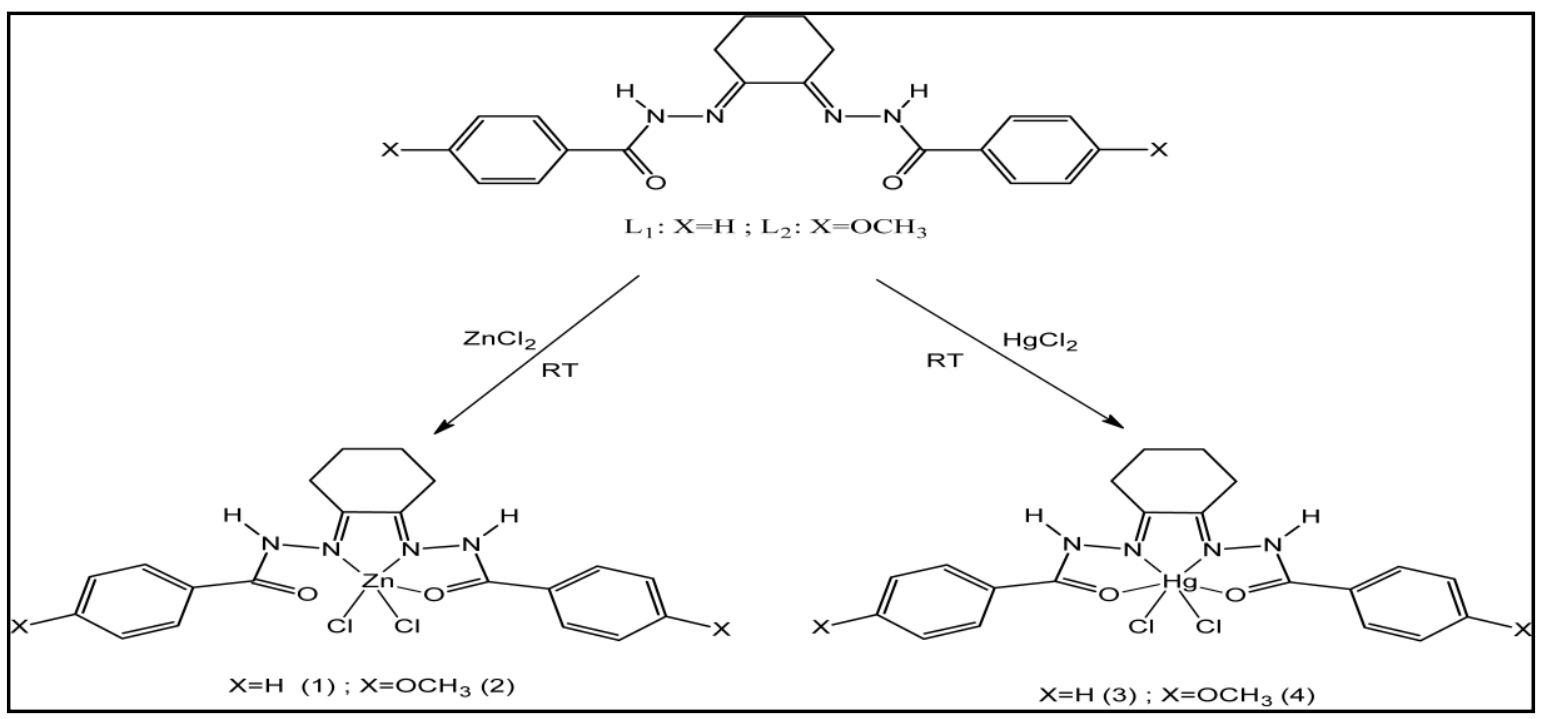

Scheme (2): Synthetic diagram for the preparation of metal complexes.

Different techniques have been used to characterize the prepared organic ligands and their metal complexes (X-ray single crystal crystallography and microelemental analyses in addition to infrared, nuclear magnetic resonance, X-ray powder diffraction, Ultra violate-visible-Near infrared, and mass spectroscopies). The ${ }^{1} \mathrm{H}$ and ${ }^{13} \mathrm{C}$ NMR spectra of $\mathrm{L}_{1}, \mathrm{~L}_{2}, \mathbf{1}, \mathbf{2}, \mathbf{3}$ and 4 in general showed signals related to the proton and carbon nuclei, see experimental part. ${ }^{1} \mathrm{H}$ NMR of these compounds displayed two triplet and one mutiplet signals at the chemical shifts range: $(1.74-2.85)$ ppm which can be attributed to the cyclohexyl protons. The multipet that appeared at the range $(6-8) \mathrm{ppm}$ is assigned to the aromatic protons. The spectra also showed the appearance of two singlet signals at different chemical shifts which are due to the $\mathrm{NH}$-keto and $\mathrm{OH}$-enol forms, for instant see Fig.(1). The infrared spectra of the organic ligands and their metal complexes showed several absorptions, belonging to $v(\mathrm{NH})$ and $v(\mathrm{C}=\mathrm{O})$ [22]. Moreover, the $v(\mathrm{C}=\mathrm{N})$ that appeared in the spectra of the free ligands is found to be shifted either at lower or higher frequencies. This may indicates that the azomethane nitrogen atom is involved in the coordination. UV-Vis-NIR spectra of $\mathrm{L}_{1}$ and $\mathrm{L}_{2}$ displayed in general, two main absorption peaks at the ranges: $\left(273-283 \mathrm{~nm}, \varepsilon_{\max }=\right.$ $\left.14,000-14,190 \mathrm{dm}^{3} \cdot \mathrm{mol}^{-1} \cdot \mathrm{cm}^{-1}\right)$ and $(338-344$ $\left.\mathrm{nm}, \varepsilon_{\max }=7,200-7,800 \mathrm{dm}^{3} \cdot \mathrm{mol}^{-1} \cdot \mathrm{cm}^{-1}\right)$ attributable to the $\pi-\pi^{*}$ and $n-\pi^{*}$ transitions, respectively. The spectra of all the prepared complexes (1-4), caused bathochromic shift of ligand band related to the $\pi-\pi *$ transition. This band was appeared at the range: $(335-342 \mathrm{~nm}$, 
$\left.\varepsilon_{\max }=15,600-18,200 \mathrm{dm}^{3} \cdot \mathrm{mol}^{-1} \cdot \mathrm{cm}^{-1}\right)$. No band related to $n-\pi *$ transition could be clearly observed in these spectra except in 4 , which shows a shoulder with low intensity, detected at $\left(430 \mathrm{~nm}, \varepsilon_{\max }=1,180 \mathrm{dm}^{3} \cdot \mathrm{mol}^{-1} \cdot \mathrm{cm}^{-1}\right)$. So, the band related to $\mathrm{n}-\pi^{*}$ in these compounds may be obscured by $\pi-\pi^{*}$ band. New band

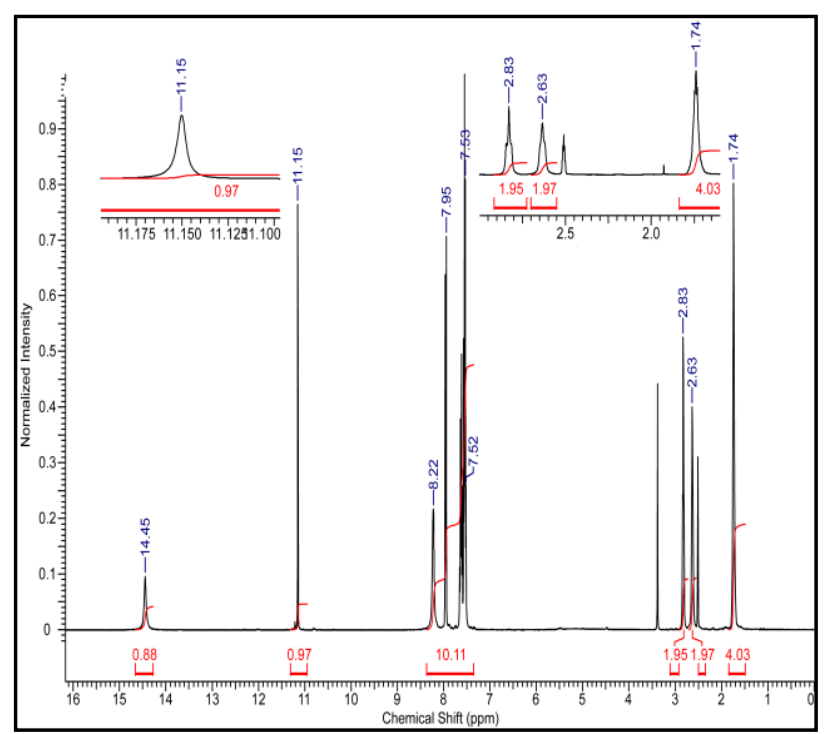

(i) were observed in all spectra of the prepared complexes at the range: $\left(385-450 \mathrm{~nm}, \varepsilon_{\max }=\right.$ 10,200-11,000 dm $\left.3 . \mathrm{mol}^{-1} . \mathrm{cm}^{-1}\right)$. These bands were assigned to charge transfer transition. No $d-d$ transitions are detected in the spectra of metal complexes, because of filled d-orbitals [23].

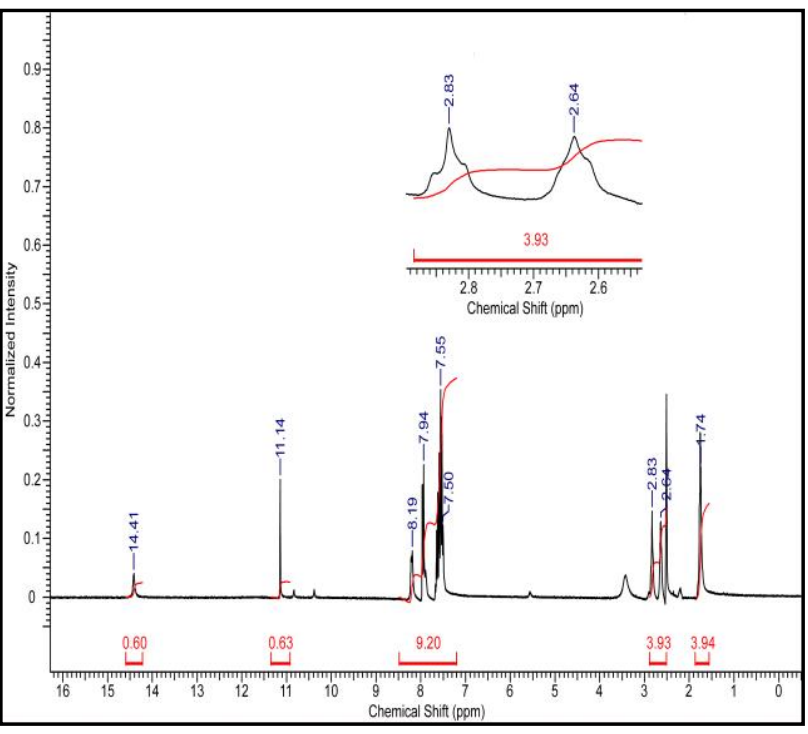

(ii)

Fig.(1): (i) ${ }^{1}$ HNMR spectrum of $L_{1}$ (ii) ${ }^{1}$ HNMR spectrum of 1 .

$\mathrm{X}$-ray structures of mononuclear-zinc and mononuclear-mercury complexes

Figures 2 show the $\mathrm{x}$-ray crystal structures of $\left[\mathrm{Zn}\left(\mathrm{L}_{1}\right) \mathrm{Cl}_{2}\right]$ (1), $\left[\mathrm{Zn}\left(\mathrm{L}_{2}\right) \mathrm{Cl}_{2}\right] \cdot \mathrm{CH}_{3} \mathrm{CN}$ (2). $\left[\mathrm{Hg}\left(\mathrm{L}_{1}\right) \mathrm{Cl}_{2}\right]$ (3) and $\left[\mathrm{Hg}\left(\mathrm{L}_{2}\right) \mathrm{Cl}_{2}\right] \cdot \mathrm{CH}_{3} \mathrm{CN}$ (4). In general, the structure of each complex comprises the $[\mathrm{M}(\mathrm{L})]^{2+}$ core $\left(\mathrm{L}: \mathrm{L}_{1}\right.$ or $\mathrm{L}_{2}, \mathrm{M}=$ $\mathrm{Zn}^{2+}$ or $\left.\mathrm{Hg}^{2+}\right)$. Furthermore, it is clearly seen from this figure that $\mathrm{L}_{1}$ and $\mathrm{L}_{2}$ are behave as planar quadridentate ligands. The zinc complexes are found to be five coordinate with square-based pyramidal (one oxygen atom and

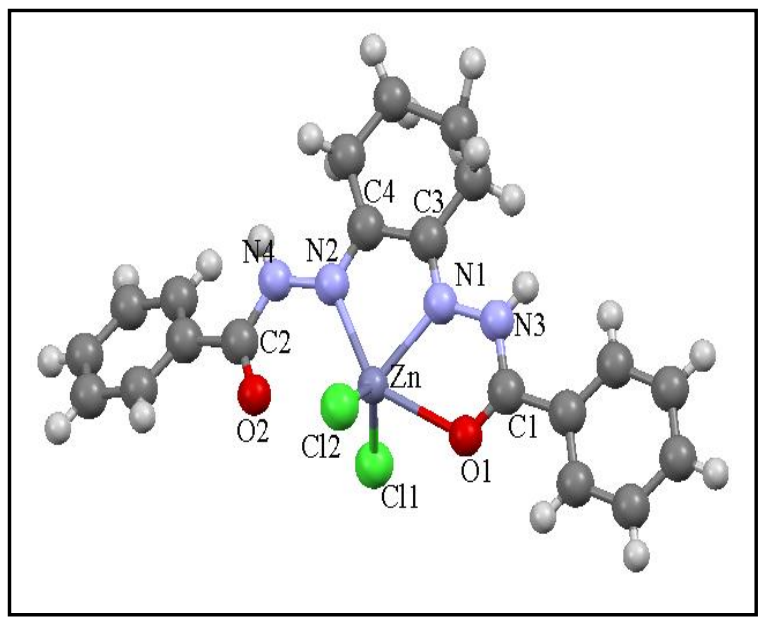

(A) two nitrogen atoms of bishydrazone ligand, and two chloro atoms), while the mercury complexes are six coordinate with octahedral geometry (two oxygen atoms and two nitrogen atoms of bishydrazone ligand, and two chloro atoms). Full details of the bonds length for compounds $\mathbf{1}$ to $\mathbf{4}$ are listed in Tables ( 2 and 3). The XRD pattern obtained experimentally is quite close to that obtained from the $\mathrm{x}$-ray crystal data of the compounds (for example see Fig.(3).

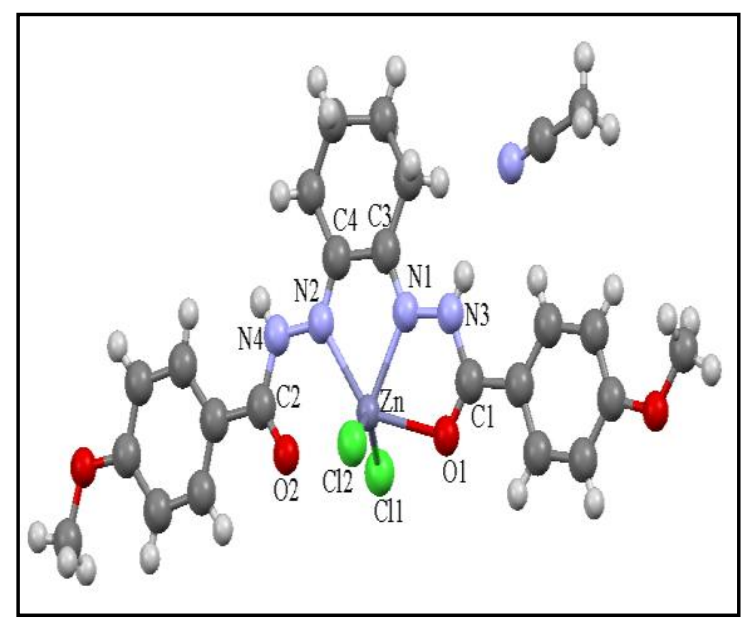

(B) 


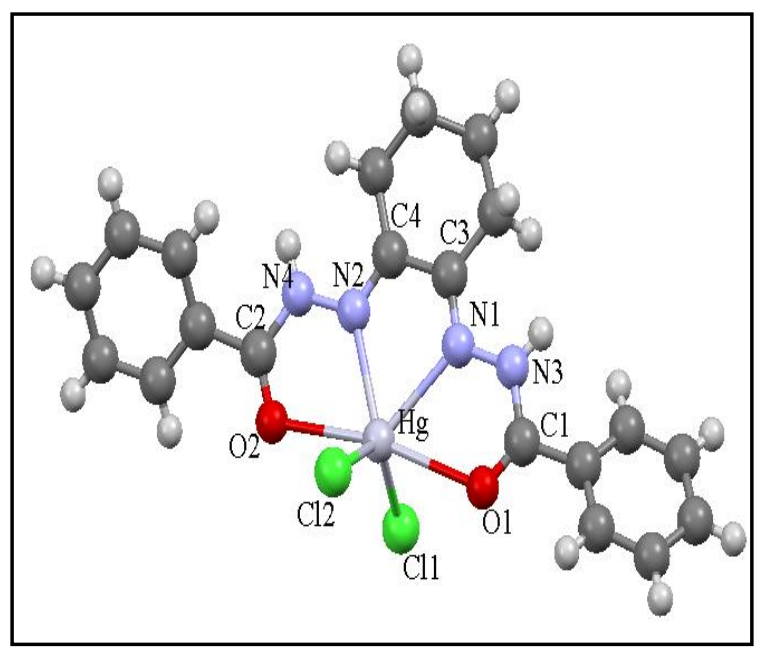

(C)

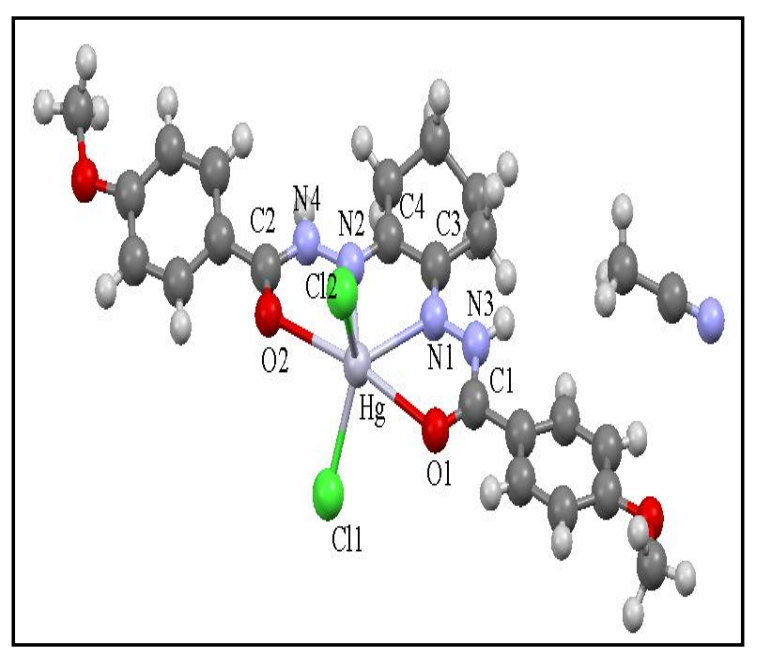

(D)

Fig.(2): X-ray crystal structures of $1(A), 2(B), 3(C)$ and 4 (D).

Table (1)

Crystal data and experimental details for 1, 2, 3 and 4.

\begin{tabular}{|c|c|c|c|c|}
\hline & 1 & 2 & 3 & 4 \\
\hline Crystal size $\left(\mathrm{mm}^{3}\right)$ & $\begin{array}{c}0.12 \times 0.11 \times \\
0.10\end{array}$ & $\begin{array}{c}0.13 \times 0.13 \times \\
0.11\end{array}$ & $\begin{array}{c}0.12 \times 0.10 \times \\
0.08\end{array}$ & $\begin{array}{c}0.32 \times 0.26 \times \\
0.12\end{array}$ \\
\hline Crystal system & Triclinic & Triclinic & Triclinic & Triclinic \\
\hline Space group & $\mathrm{P} 1$ & $\mathrm{P} 1$ & $\mathrm{P} 1$ & $\mathrm{P} 1$ \\
\hline \multicolumn{5}{|l|}{ Unit cell dimensions $\left(\AA,{ }^{\circ}\right)$ : } \\
\hline a & $9.0312(2)$ & $10.1345(3)$ & $9.0881(2)$ & $11.2103(15)$ \\
\hline $\mathbf{b}$ & $10.5576(2)$ & $10.7268(3)$ & $10.3420(3)$ & $11.8606(16)$ \\
\hline 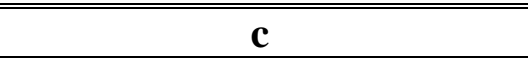 & $11.6525(2)$ & $13.5438(4)$ & $11.2757(3)$ & $19.223(3)$ \\
\hline$\alpha$ & $86.050(1)$ & $777.386(1)$ & $81.983(2)$ & $86.901(5)$ \\
\hline$\beta$ & $82.484(1)$ & $70.445(1)$ & $80.153(2)$ & $76.165(4)$ \\
\hline$\gamma$ & $80.855(1)$ & $65.529(2)$ & $83.188(1)$ & $75.252(4)$ \\
\hline Volume $\left(\AA^{3}\right)$ & $1086.18(4)$ & $1257.33(6)$ & $1029.09(5)$ & $2399.9(6)$ \\
\hline Temperature $(\mathrm{K})$ & $133(2)$ & $133(2)$ & $133(2)$ & $120(2)$ \\
\hline $\mathrm{F}(000)$ & 496 & 604 & 596 & 1364 \\
\hline Absorption coefficient $\left(\mathrm{mm}^{-1}\right)$ & 1.400 & 1.231 & 7.763 & 6.676 \\
\hline $\begin{array}{l}\text { Theta range for data collection } \\
\qquad\left({ }^{\circ}\right)\end{array}$ & 2.57 to 27.48 & 2.10 to 27.48 & 1.85 to 27.48 & 1.09 to 32.60 \\
\hline Reflections collected & 7692 & 9514 & 6183 & 51449 \\
\hline Independent reflections & $\begin{array}{c}4898 \\
\mathrm{R}(\text { int })= \\
0.0172 \\
\end{array}$ & $\begin{array}{c}5598 \\
\mathrm{R}(\text { int })= \\
0.0230 \\
\end{array}$ & $\begin{array}{c}4600 \\
\text { R(int) }= \\
0.0441 \\
\end{array}$ & $\begin{array}{c}13435 \\
\mathrm{R}(\text { int })= \\
0.0480\end{array}$ \\
\hline Trans $\max / \mathrm{min}$ & $\begin{array}{c}0.7456 / \\
0.6342 \\
\end{array}$ & $\begin{array}{c}0.7456 / \\
0.6640\end{array}$ & $\begin{array}{c}0.7456 / \\
0.3763 \\
\end{array}$ & $\begin{array}{l}0.5013 / \\
0.2238\end{array}$ \\
\hline Final $R$ indices $[I>2 \operatorname{sigma}(I)]$ & $\begin{array}{c}\mathrm{R} 1=0.0307 \\
\mathrm{wR} 2= \\
0.0672\end{array}$ & $\begin{array}{c}\mathrm{R} 1=0.0315 \\
\mathrm{wR} 2= \\
0.0716\end{array}$ & $\begin{array}{c}\mathrm{R} 1=0.0558 \\
\mathrm{wR} 2= \\
0.1331\end{array}$ & $\begin{array}{c}\mathrm{R} 1=0.0245 \\
\mathrm{wR} 2= \\
0.0481\end{array}$ \\
\hline indices (all data) & $\begin{array}{c}\mathrm{R} 1=0.0339 \\
\mathrm{wR} 2= \\
0.0693\end{array}$ & $\begin{array}{c}\mathrm{R} 1=0.0357 \\
\mathrm{wR} 2= \\
0.0745\end{array}$ & $\begin{array}{c}\mathrm{R} 1=0.0694 \\
\mathrm{wR} 2= \\
0.1432\end{array}$ & $\begin{array}{c}\mathrm{R} 1=0.0360 \\
\mathrm{wR} 2= \\
0.0515\end{array}$ \\
\hline
\end{tabular}


Table (2)

Selected bond lengths in 1 and 2.

\begin{tabular}{||l||c||c|}
\hline & 1 & 1 \\
\hline \hline $\mathrm{Zn}(1)-\mathrm{O}(1)$ & $2.3711(14)$ & $2.3704(14)$ \\
\hline $\mathrm{Zn}(1)-\mathrm{N}(1)$ & $2.1293(16)$ & $2.1600(15)$ \\
\hline $\mathrm{Zn}(1)-\mathrm{N}(2)$ & $2.2154(15)$ & $2.2135(16)$ \\
\hline $\mathrm{Zn}(1)-\mathrm{Cl}(1)$ & $2.2268(5)$ & $2.2366(5)$ \\
\hline $\mathrm{Zn}(1)-\mathrm{Cl}(2)$ & $2.2419(5)$ & $2.2595(5)$ \\
\hline $\mathrm{C}(3)-\mathrm{N}(1)$ & $1.2811(3)$ & $1.2887(2)$ \\
\hline $\mathrm{C}(4)-\mathrm{N}(2)$ & $1.2944(2)$ & $1.2924(2)$ \\
\hline $\mathrm{C}(1)-\mathrm{N}(3)$ & $1.3623(3)$ & $1.3765(2)$ \\
\hline $\mathrm{C}(2)-\mathrm{N}(4)$ & $1.3782(2)$ & $1.3894(2)$ \\
\hline $\mathrm{C}(1)-\mathrm{O}(1)$ & $1.2189(2)$ & $1.2229(2)$ \\
\hline $\mathrm{C}(2)-\mathrm{O}(2)$ & $1.2150(2)$ & $1.2190(2)$ \\
\hline $\mathrm{C}(3)-\mathrm{C}(4)$ & $1.4894(2)$ & $1.4920(2)$ \\
\hline $\mathrm{N}(1)-\mathrm{N}(3)$ & $1.3741(2)$ & $1.3645(2)$ \\
\hline $\mathrm{N}(2)-\mathrm{N}(4)$ & $1.3665(2)$ & $1.3688(2)$ \\
\hline
\end{tabular}

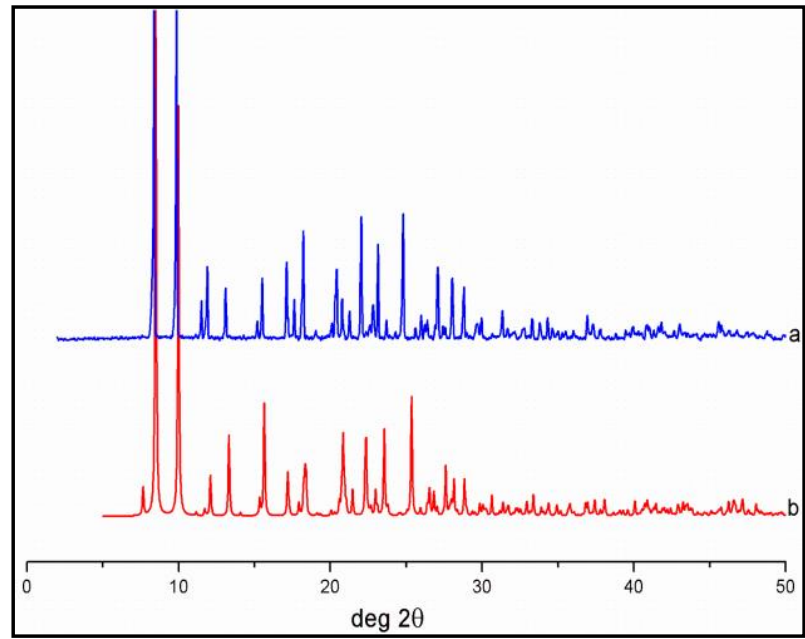

Fig. (3): X-ray diffraction patterns of 1: (a) pattern that obtained experimentally; (b) pattern that calculated from the $x$-ray data.

Table (3)

Selected bond lengths in 3 and 4.

\begin{tabular}{|c|c|c|}
\hline & 3 & 4 \\
\hline \hline $\mathrm{Hg}(1)-\mathrm{O}(1)$ & $2.7329(8)$ & $2.674(2)$ \\
\hline $\mathrm{Hg}(1)-\mathrm{O}(2)$ & $2.6960(10)$ & $2.652(2)$ \\
\hline \hline $\mathrm{Hg}(1)-\mathrm{N}(1)$ & $2.4743(8)$ & $2.452(2)$ \\
\hline $\mathrm{Hg}(1)-\mathrm{N}(2)$ & $2.4240(10)$ & $2.446(2)$ \\
\hline $\mathrm{Hg}(1)-\mathrm{Cl}(1)$ & $2.4039(3)$ & $2.4137(6)$ \\
\hline $\mathrm{Hg}(1)-\mathrm{Cl}(2)$ & $2.3986(2)$ & $2.3779(6)$ \\
\hline $\mathrm{C}(3)-\mathrm{N}(1)$ & $1.2921(15)$ & $1.291(3)$ \\
\hline $\mathrm{C}(4)-\mathrm{N}(2)$ & $1.2871(14)$ & $1.281(3)$ \\
\hline $\mathrm{C}(1)-\mathrm{N}(3)$ & $1.3635(15)$ & $1.381(3)$ \\
\hline $\mathrm{C}(2)-\mathrm{N}(4)$ & $1.3717(14)$ & $1.376(3)$ \\
\hline $\mathrm{C}(1)-\mathrm{O}(1)$ & $1.2266(13)$ & $1.211(3)$ \\
\hline $\mathrm{C}(2)-\mathrm{O}(2)$ & $1.2299(13)$ & $1.218(3)$ \\
\hline \hline $\mathrm{C}(3)-\mathrm{C}(4)$ & $1.4823(14)$ & $1.480(4)$ \\
\hline \hline $\mathrm{N}(1)-\mathrm{N}(3)$ & $1.3509(12)$ & $1.362(3)$ \\
\hline
\end{tabular}

\section{Antibacterial study}

Wide spectrum of biological activities of hydrazide and hydrazone type compounds are already reported in the literatures which showed the remarkable properties of such compounds, for example see reference 24 . In this work, the prepared organic ligands and their metal complexes displayed an interesting biological activity against Staphylococcus aureus and Escherichia coli bacteria. The percentage of inhibition of growth was about 73-83\%, see Fig.(4).

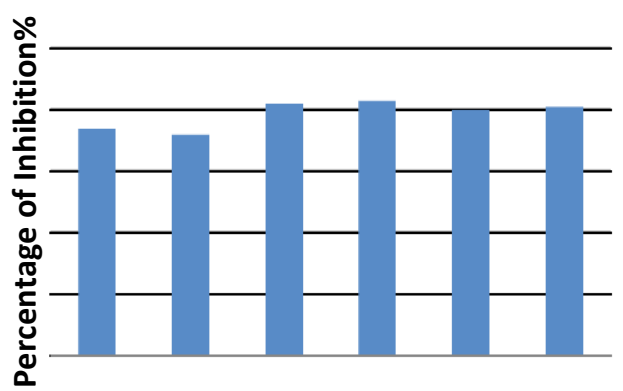

- Staphylococ cus aureus

Fig.(4): Percentage of inhibition of some pathogenic bacteria by the prepared compounds.

\section{Kinetics studies}

Stopped-flow spectrophotometry was used to study the kinetics of the reactions between $\mathrm{L}_{2}$ and $\mathrm{Zn}(\mathrm{II})$. The reactions were studied under pseudo-first-order conditions with $\left[\mathrm{L}_{2}\right] \geq$ $10\left[\mathrm{Zn}^{2+}\right]$ monitoring the reaction at $\lambda=430$ nm. Fig.(5), shows that the absorbance-time traces is fitted to a single exponential curve, which indicates a first-order of the reactions depending upon the concentration of zinc ion. This was confirmed in studies where the concentration of zinc ion was varied in the range: $0.2-1.0 \mathrm{mmol} \mathrm{dm}^{-3}$ and the concentration of $\mathrm{L}_{2}$ was $10 \mathrm{mmol} \mathrm{dm}^{-3}$, but nevertheless, the values of the observed rate constants $\left(k_{o b s}\right)$ for each reaction were almost constant. The reactions displaying a first-order dependence on the concentration of $\mathrm{L}_{2}$, as 
typified by the plot shown in Fig.(5) and the corresponding rate law in equation (1). As in our previous work $[15,16,25,26]$, the initial binding of $\mathrm{L}_{2}$ to $\left[\mathrm{Zn}(\mathrm{NCMe})_{4}\right]^{2+}$ by replacement of one of the coordinated $\mathrm{CH}_{3} \mathrm{CN}$ molecules represents the rate-limiting step of the chelate formation. The mechanism for such a reaction is focus on the generation of $\left[\mathrm{Zn}(\mathrm{NCMe})_{(n-1)}\right]^{2+}$ (with a vacant site at which $\mathrm{L}_{2}$ can bind (Scheme 3a)) through the dissociation of a coordinated solvent from $\left[\mathrm{Zn}(\mathrm{NCMe})_{n}\right]^{2+}$. The full rate law for this mechanism is shown in equation (2). When the concentration of $\mathrm{L}_{2}$ is small, $\mathrm{k}_{-1}[\mathrm{MeCN}]>\mathrm{k}_{2}$ $\left[\mathrm{L}_{2}\right]$ the rate law would simplify to that shown in equation (3), which is of the same form as observed experimentally in eqn (1) $\left(\mathrm{k}_{\mathrm{a}}=\mathrm{k}_{1} \mathrm{k}_{2}\right.$ $\left./ \mathrm{k}_{-1}[\mathrm{MeCN}]\right)$.

$$
\begin{aligned}
& -\mathrm{d}\left[\mathrm{Zn}^{2+}\right] / \mathrm{dt}=\mathrm{k}_{\mathrm{a}}\left[\mathrm{L}_{2}\right]\left[\mathrm{Zn}^{2+}\right] \\
& -\mathrm{d}\left[\mathrm{Zn}^{2+}\right] / \mathrm{dt}=\mathrm{k}_{1} \mathrm{k}_{2}\left[\mathrm{~L}_{2}\right]\left[\mathrm{Zn}^{2+}\right] / \mathrm{k}_{-1}[\mathrm{MeCN}]+ \\
& \mathrm{k}_{2}\left[\mathrm{~L}_{2}\right] \\
& -\mathrm{d}\left[\mathrm{Zn}^{2+}\right] / \mathrm{dt}=\mathrm{k}_{1} \mathrm{k}_{2}\left[\mathrm{~L}_{2}\right]\left[\mathrm{Zn}^{2+}\right] / \mathrm{k}_{-1}[\mathrm{MeCN}]
\end{aligned}
$$

Our previous study $[15,16]$ reports the kinetic of the reaction of $\mathrm{L}_{2}$ with $\mathrm{Cu}^{2+}$ [15] or with $\mathrm{Hg}^{2+}$ [16]. In case of $\mathrm{Hg}^{2+}$, the story is quite similar to that of $\mathrm{Zn}^{2+}$, except that the rate constant of the formation of mercury complex (4) is lower than that of zinc complex (2). All attempts to study the kinetics of the reactions between $\mathrm{L}_{1}$ and metal ions $\left(\mathrm{Zn}^{2+}\right.$ or $\mathrm{Hg}^{2+}$ ), were unsuccessful, because of the lack solubility of $\mathrm{L}_{1}$ in acetonitrile!

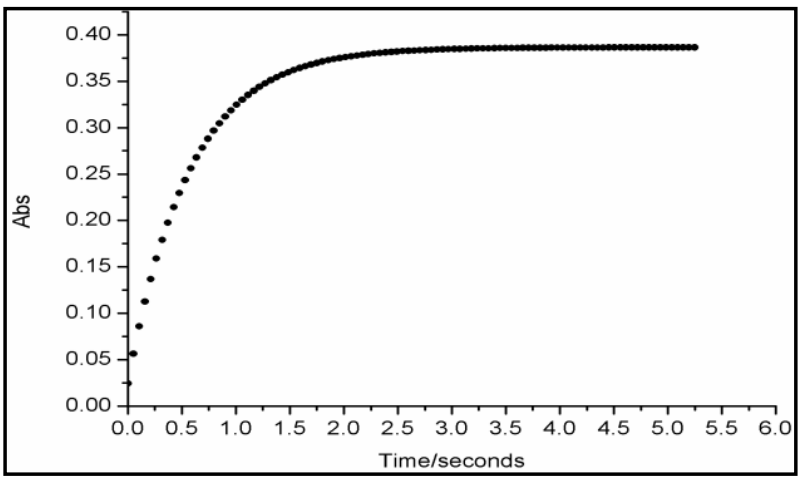

(i)

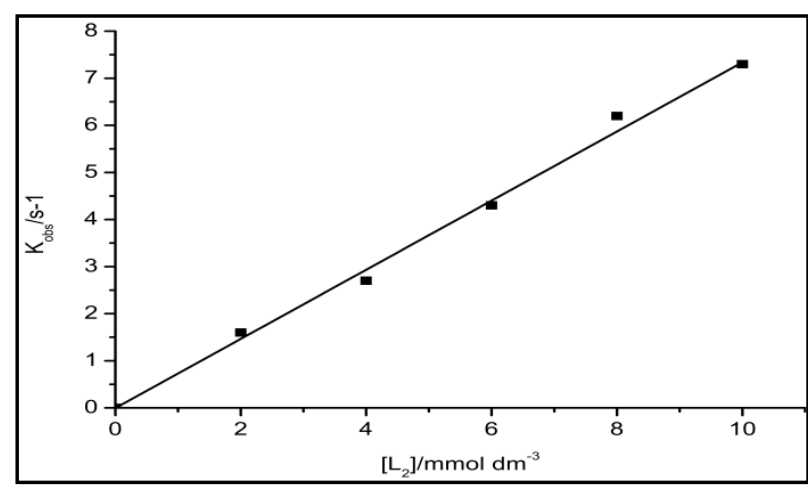

(ii)

Fig.(5): Kinetic studies for the formation of $2 i$ ) Curve of the absorbance as a function of time ii) the first order dependence of the $k_{\text {obs }}$ on the concentration of $L_{2}\left(k_{o b s}=7.4 \times 10^{2}\left[L_{2}\right]\right)$.

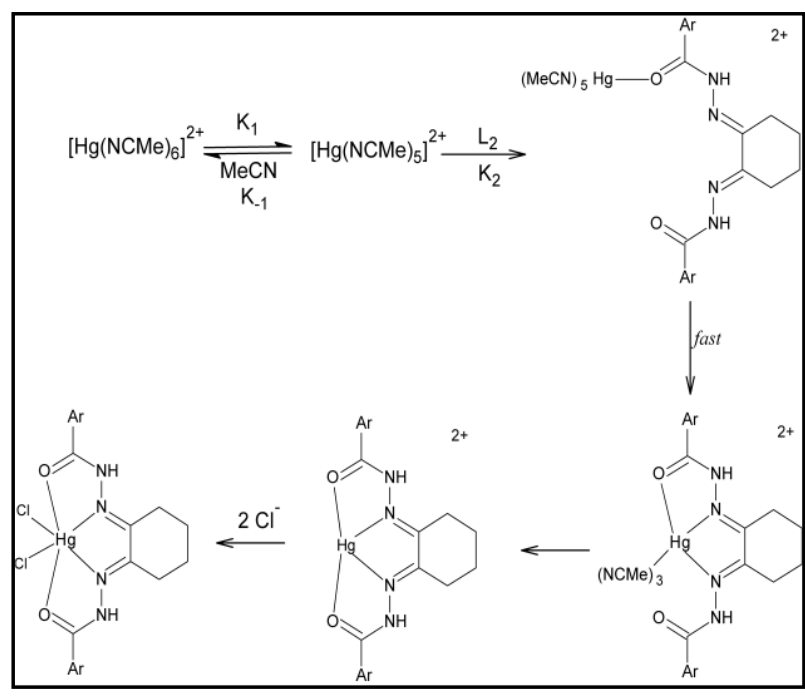

(i)

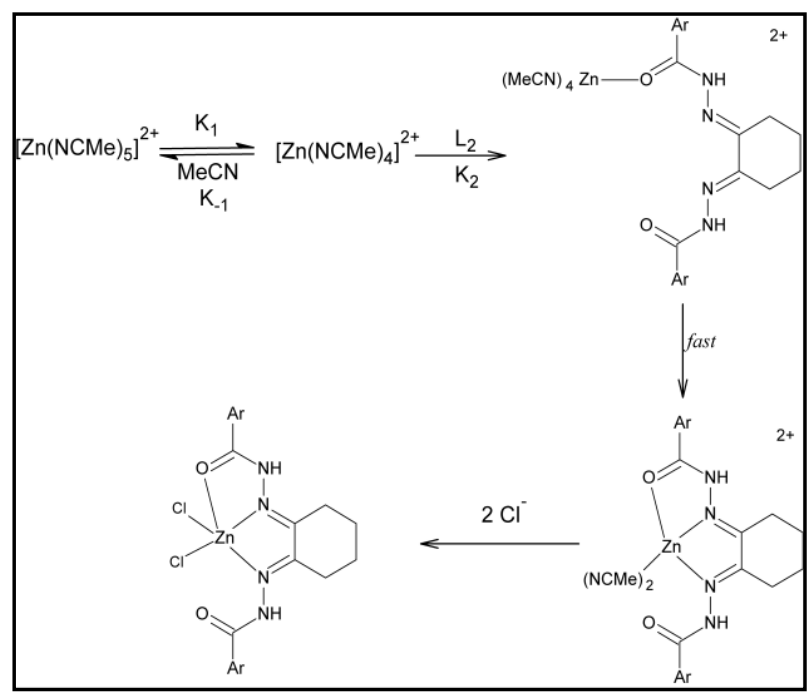

(ii)

Scheme (3): Kinetic mechanisms for the formation of 2 (i), and 4 (ii). 


\section{References}

[1] Maheswari R., Manjula J., Veeramanikandan S. and Sherine H.B., Synthesis and characterization of novel benzohydrazide derivatives, Der. Chemica. Sinica, 5, 42-47, 2014.

[2] Campodónico P.R., Aliaga M.E., Santos J.G., Castro E.A. and Contreras R., Reactivity of benzohydrazide derivatives towards acetylation reaction. Experimental and theoretical studies, Chem. Phys. Lett., 488, 86-89, 2010.

[3] López-Torres E. and Mendiola M.A., Structural diversity of benzil bis (benzoylhydrazone): Mononuclear, binuclear and trinuclear complexes, Dalton Trans.,7639-7647, 2009.

[4] Bedia K.-K., Elçin O., Seda U., Fatma K., Nathaly S., Sevim R. and Dimoglo A., Synthesis and characterization of novel hydrazide-hydrazones and the study of their structure-antituberculosis activity, Eur. J. Med. Chem., 41, 1253-1261, 2006.

[5] Guru M.M. and Punniyamurthy T., Copper (II)-Catalyzed Aerobic Oxidative Synthesis of Substituted 1, 2, 3-and 1, 2, 4-Triazoles from Bisarylhydrazones via $\mathrm{C}-\mathrm{H}$ Functionalization/C-C/N-N/C-N Bonds Formation, J. Org. Chem., 77, 5063-5073, 2012.

[6] Rollas S. and Küçükgüzel S.G., Biological activities of hydrazone derivatives, Molecules, 12, 1910-1939, 2007.

[7] Narang R., Narasimhan B. and Sharma S., A review on biological activities and chemical synthesis of hydrazide derivatives, Current Med. Chem., 19, 569-612, 2012.

[8] Negi V. J., Sharma A.K., Negi J.S. and Ra V., Biological activities of hydrazone derivatives in the new millennium, Int. J. Pharm. Chem., 4, 100-109, 2012.

[9] Bermejo M.R., Fondo M., González A.M., Hoyos O.L., Sousa A., McAuliffe C.A., Hussain W., Pritchard R. and Novotorsev V.M., Electrochemical synthesis and structural characterisation of transition metal complexes with 2, 6-bis (1salicyloylhydrazonoethyl) pyridine, $\mathrm{H} 4$ daps, J. Chem. Soc., Dalton Trans., 22112218, 1999.

[10] Feuer H. and Harmetz R., The Reaction of Maleic Hydrazide with Formaldehyde and
Alcohols in Acidic Medium1, 2, J. Org. Chem., 24, 1501-1504, 1959.

[11] Carcelli M., Mazza P., Pelizzi C. and Zani F., Antimicrobial and genotoxic activity of 2, 6-diacetylpyridine bis (acylhydrazones) and their complexes with some first transition series metal ions. X-ray crystal structure of a dinuclear copper (II) complex, J. Inorg. Biochem., 57, 43-62, 1995.

[12] Shaban M., Nassr M., El Ashry E. and Mustafa M., Reactions of aroylhydrazones. III: oxidative cyclization of cyclohexane1,2-dione bis(aroylhydrazones) to substituted 1,2,3-triazoles, Org. Prep. Proc. Int., 9, 117-124, 1977.

[13] Vigato P. and Tamburini S., Advances in acyclic compartmental ligands and related complexes, Coord. Chem. Rev., 252, 18711995, 2008.

[14] Naskar S., Corbella M., Blake A.J. and Chattopadhyay S.K., Versatility of 2, 6diacetylpyridine (dap) hydrazones in generating varied molecular architectures: Synthesis and structural characterization of a binuclear double helical Zn (II) complex and a Mn (II) coordination polymer, Dalton Trans., 1150-1159, 2007.

[15] Al-Karawi A. J. M., Maatta E., Desper J., Maurmann L., Henderson R. A., Buchholz A. and Plass W., Synthesis, structure, magnetic properties and kinetics of formation of a cluster containing a $\left\{\mathrm{Cu}_{3}\right.$ $\left.\left(\mu_{3}-\mathrm{OH}\right)\right\}$ core supported by a triazole-based ligand. J. Coord. Chem. 69 (3), 458-474, 2016.

[16] Al-Karawi A.J.M., Comprehensive comparison between the reaction of $\mathrm{N}, \mathrm{N}^{\prime}$ cyclohexane-1, 2-diylidene-bis (4methoxybenzoylhydrazide) with mercury (II) and copper (II) ions. Synthesis, structure, and kinetics of complex formation. Russ. J. Coord. Chem. 43 (2), 113-126, 2017.

[17] Bruker Analytical X-ray Systems, APEX2 v2013.10-0, Madison, Wiskonsin, USA, 2013.

[18] Bruker Analytical X-ray Systems, COSMO v1.61, Madison, Wiskonsin, USA, 1999.

[19] Bruker Analytical X-ray Systems, SAINT v8.34a, Madison, Wiskonsin, USA, 1997. 
[20] Bruker Analytical X-ray Systems, SADABS v2012/1, Madison, Wiskonsin, USA, 2012.

[21] Bruker Analytical X-ray Systems, SHELXTL v2013/4, Madison, Wiskonsin, USA, 2013.

[22] R. Silverstien, F. Webster, D. Kiemle. Spectrophotometric Identification of Organic Compounds. $7^{\text {th }}$ edn. Willy, New York, 2005.

[23] Lever, A., Inorganic Electronic Spectroscopy, $1^{\text {st }}$ edn. Elesvier Publishing, New York, 1984.

[24] Verma G., Marella A., Shaquiquzzaman M., Akhtar M., Ali M. R. and Alam M. M., A review exploring biological activities of hydrazones. J. Pharm. Bioallied Sci., 6 (2), 69, 2014.

[25] Al-Karawi A. J. M., Clegg W., Harrington R. W. and Henderson, R. A., Synthetic, structural and kinetic studies on the binding of cyclohexane-1, 2-bis (4-methyl-3thiosemicarbazone) to divalent metal ions (Co, Ni, Cu, Zn or Cd). Dalton Trans., 564$570,2009$.

[26] Al-Karawi A. J. M., Synthesis and characterization of a new N2S2 Schiff base ligand and its complexes with nickel (II), copper (II) and cadmium (II) including the kinetics of complex formation. Trans. Met. Chem., 34 (8), 891-897, 2009. 